\title{
PENGARUH CORPORATE GOVERNANCE TERHADAP KONDISI FINANCIAL DISTRESS PADA PERUSAHAAN CV. OTOPRO MOBILINDO
}

\author{
Firmayanti, Febryandhie Ananda \\ Sekolah Tinggi Ilmu Ekonomi KBP \\ Email: firma.060892@gmail.com \\ febryandhie@akbpstie.ac.id
}

\begin{abstract}
ABSTRACK
Financial distress is a stage of decreasing the company's financial condition, bad finance will result in bankruptcy of the company. This study aims to analyze the influence of corporate governance on financial distress. The indicator in this study is profitability, this study uses 36 samples from financial statements. CV. Otopro Mobilindo in 2015 - 2017 which was then analyzed using the SPSS For Windows 23. application This study used a classic assumption test consisting of normality, linearity and autocorrelation tests. The results of simple regression analysis show that the coefficient value of the corporate governance variable has a significant $t$ test ( $t$ count). This shows that there is a negative and significant influence on corporate governance variables on financial distress in $C V$. Otopro Mobilindo. From the results of the determination test shows that the $R$ Square coefficient increases and the variable financial distress conditions can be explained by corporate governance variables. While the rest is influenced by other variables not examined in this study related to financial stress.
\end{abstract}

Keywords : Corporate governance, Financial distress condition.

\section{PENDAHULUAN}

\section{Latar Belakang Masalah}

Di Indonesia perkembangan dunia usaha tumbuh semakin pesat yang akan menimbulkan suatu dampak bagi perusahaan lainnya, yaitu ditandai dengan semakin ketatnya persaingan antara perusahaan yang bergerak dibidang yang sama. Kinerja perusahaan dapat diketahui dari hasil laporan keuangan perusahaan tersebut. Hasil laporan keuangan yang telah dianalisis dapat menggambarkan hasil kinerja suatu perusahaan yang dapat digunakan sebagai penentu keputusan bagi pemilik perusahaan. Uji rasio dapat juga dijelaskan saling berkaitan antara variabel - variabel bersangkutan yang menghubungkan dua data keuangan (neraca dan laporan laba rugi), dengan cara membagi satu data dengan lainnya menurut [1].

Masalah keuangan perusahaan dapat terjadi dengan berbagai penyebab, contohnya perusahaan yang mengalami rugi berkepanjangan, diakibatkan karena penjualan tidak laku, serta bencana alam oleh sebab itu menyebabkan aset perusahaan rusak, sistem tata kelola perusahaan yang tidak baik atau disebabkan oleh karena kondisi perekonomian negara yang kurang stabil memicu timbulnya kesulitan keuangan. Dasar penyebab timbulnya kritis ekonomi di Indonesia serta 
di berbagai negara Asia lainnya ialah buruknya pelaksanaan good governace hampir di semua perusahaan yang ada, baik perusahaan yang dimiliki pemerintah (BUMN) maupun yang dimiliki oleh swasta.

Financial distress dialami pada setiap perusahaan, baik itu perusahaan yang berukuran besar maupun berukuran kecil karena faktor penyebab kesulitan keuangan dapat berasal dari pihak dalam maupun pihak luar perusahaan [2]. Semakin baik penerapan mekanisme tata kelola perusahaan maka perusahaan akan berada dalam kondisi yang baik, sehingga dapat meningkatkan kinerja perusahaan yang bersangkutan serta mengurangi kecendrungan kondisi financial distress pada sebuah perusahaan [3], [4]. Walaupun demikian, berdasarkan data pengamatan yang diperoleh dari perusahaan CV. Otopro Mobilindo pada laporan keuangan periode 2015-2017 tercatat sebanyak 36 data yang diperoleh masing-masing dari laporan laba rugi dan neraca/aset perbulan.

Financial distress perlu untuk dikembangkan karena dengan mengetahui kondisi kesulitan keuangan perusahaan diharapkan dapat dilakukan tindakan untuk mengantisipasi kondisi yang mengarah pada kebangkrutan. Laporan keuangan yang diterbitkan perusahaan merupakan salah satu sumber informasi mengenai posisi keuangan perusahaan, kinerja serta perubahan posisi keuangan perusahaan, yang sangat berguna untuk mendukung pengambilan keputusan yang tepat. Agar informasi yang tersaji menjadi lebih bermanfaat dalam pengambilan keputusan, data keuangan harus dikonversi menjadi informasi yang berguna dalam pengambilan keputusan ekonomis. Salah satu contoh perusahaan yang bergerak di Bidang Penjualan Barang / Jasa Pencucian Mobil dan Salon Mobil yaitu CV. Otopro Mobilindo dalam biaya Operasionalnya mengalami penurunan laba setiap bulannya meskipun tidak terlalu menonjol. Terdapat pada tahun 2017 bulan februari memperoleh laba sebesar Rp. 9.148.100,- sedangkan 2 bulan berikutnya memperoleh penurunan laba yaitu bulan maret Rp. 8.203.700,- dan bulan april sebesar Rp.7.154.500,- penyebab salah satunya adalah pengeluaran yang terlalu berlebihan.

Rasio yang digunakan untuk memprediksi terjadinya financial distress adalah rasio profitabilitas. Rasio profitabilitas adalah indikator sebagai pusat dari sistem keuangan Jiming dalam [5]. Rasio profitabilitas merupakan rasio yang digunakan untuk mengukur kemampuan perusahaan dalam memperoleh laba atau keuntungan, profitabilitas suatu perusahaan mewujudkan perbandingan antara laba dengan aktiva atau modal yang menghasilkan laba tersebut [5]. Rasio ini menggunakan proksi Return on Assets (ROA). ROA digunakan untuk mengukur efektivitas perusahaan didalam menghasilkan keuntungan dengan memanfaatkan aktiva yang dimilikinya. ROA merupakan rasio profitabilitas yang paling sering digunakan oleh penelitian sebelumnya. Penelitian yang dilakukan oleh Almilia dalam [5] menunjukkan bahwa NITA atau ROA berpengaruh terhadap terjadinya kondisi financial distress. Penelitian lainnya dilakukan oleh [5] yang menunjukkan bahwa ROA berpengaruh positif dan signifikan terhadap terjadinya kesulitan keuangan. Penelitian serupa juga dilakukan oleh Pranowo dkk dalam [5] dengan menganalisis faktor internal dan eksternal yang mempengaruhi financial distress perusahaan. Hasilnya bahwa rasio CA/CL, EBITDA/TA, EQ/TA berpengaruh positif dan signifikan terhadap financial distress.

Terdapat beberapa penelitian sebelumnya mengenai financial distress Penelitian Sebelumnya [6] Hasil penelitian menunjukan bahwa Corporate 
Governance berpengaruh negatif terhadap Kondisi Financial Distress. Dan menurut [5] hasil penelitiannya juga menunjukan bahwa Corporate Governance berpengaruh negatif terhadap Kondisi Financial Distress.

Berdasarkan latar belakang masalah diatas penulis tertarik melakukan penelitian dengan judul "PENGARUH CORPORATE GOVERNANCE TERHADAP KONDISI FINANCIAL DISTRESS PADA PERUSAHAAN CV. OTOPRO MOBILINDO"

\section{METODE PENELITIAN}

\section{Jenis Penelitian}

Penelitian ini menggunakan metode kuantitatif. Berdasarkan latar belakang dan kerangka pemikiran yang dikemukakan pada bab sebelumnya, maka yang menjadi objel penelitian ini adalah variable $\mathrm{X}$ (corporate governance) dan variable Y (kondisi financial distress).

\section{Objek Penelitian}

Dalam penelitian ini, penulis memilih lokasi di padang salah satu perusahaan otomotif CV. Otopro Mobilindo, yang berlokasi di Jalan H.Agus salim no. 63. Karena penulis menganggap bahwa lokasi tersebut sangat cocok dengan ruang lingkup penelitian yang penulis lakukan. Penetapan tempat penelitian pada lokasi ini didasarkan pada pertimbangan bahwa obyek tersebut dapat memberikan keterangan yang lengkap tentang masalah yang diteliti yakni data yang diperlukan cukup memadai, dan lokasi tersebut mudah dijangkau sehingga dari segi waktu, biaya dan tenaga cukup menunjang bagi penulis. Perusahaan ini bergerak dibidang jasa salon dan pencucian mobil.

\section{Jenis dan Sumber Data}

Jenis data yang digunakan penulis dalam penelitian ini adalah jenis data rasio dimana angka yang diberikan kepada variabel mempunyai arti sebagai label saja dan tidak menunjukkan tingkatan apapun serta data yang digunakan bersumber dari data sekunder. Data sekunder merupakan data-data yang diperoleh dari CV. Otopro Mobilindo berupa data laporan keuangan perusahaan dari tahun 2015 - 2017.

Dilihat dari segi cara perolehannya maka penelitian ini menggunakan sumber data, yaitu data sekunder. Dalam penelitian ini adalah data yang diperoleh dari laporan posisi keuangan (neraca) dan laporan laba rugi CV. Otopro Mobilindo tahun 2015 sampai dengan tahun 2017 dengan periode pengamatan berbentuk kuartal. Karena data yang diperoleh berbentuk bulanan maka untuk memperoleh data kuartal dilakukan dengan cara interpolasi.

\section{Teknik Pengumpulan Data}

Teknik pengumpulan data merupakan langkah-langkah yang paling utama dalam penelitian, karena tujuan utama penelitian adalah mendapatkan data. Teknik pengumpulan data pada penelitian adalah metode Dokumentasi. Dokumen merupakan catatan peristiwa yang sudah berlalu. Dokumen yang digunakan peneliti disini berupa laporan keuangan periode 2015 - 2017 yang berhubungan dengan operasioal perusahaan. 


\section{Teknik Analisa Data}

Uji Asumsi Klasik

\section{Uji Normalitas}

Uji normalitas bertujuan untuk mengidentifikasi bahwa data yang diperoleh berdistribusi normal.Data yang berdistribusi normal dianggap mewakili populasi secara lebih akurat dan presisi.Distribusi normal merupakan pra-syarat untuk melakukan pengujian dengan statistic parametik.

\section{Regresi Linear Sederhana}

Regresi linear sederhana dilakukan untuk mengetahui ada atau tidaknya hubungan antara variable dependen (Y) dengan variable independen $(\mathrm{X})$. Regresi linear sederhana ini dapat dirumuskan sebagai berikut :

$$
\begin{aligned}
& \boldsymbol{Y}=\boldsymbol{a}+\boldsymbol{b} \boldsymbol{X}+\mathbf{e} \\
& \text { Dimana }: \\
& \mathrm{Y}=\text { Kondisi Financial Distress } \\
& \mathrm{X}=\text { Corporate Governance } \\
& \mathrm{a}=\text { Nilai konstan } \\
& \mathrm{b}=\text { Koefisien arah regresi }
\end{aligned}
$$

\section{Uji Autokorelasi}

Dipergunakan untuk data yang menggunakan sistem time series atau berurutan waktu. Tujuan autokorelasi untuk melihat sifat korelasi antara variabel pengganggu pada periode tertentu dengan sebelumnya. Pengujian autokorelasi pada model regresi dilaksanakan dengan Durbin Watson Test, yaitu dengan melihat nilai DW dimana apabila bila DW > Du atau (4-DW) $>$ Du maka disimpulkan tidak ada autokorelasi untuk metode dengan menggunakan pengujian regresi linear sederhana dapat terbentuk melalui hubungan fungsional/kausal per variabel (independen dan dependen) secara satu per satu [7].

\section{Uji Hipotesis}

Secara statistik merupakan ketepatan fungsi regresi dalam menaksirkan nilai aktual dapat diukur melalui koefisien determinasi, nilai statistik $\mathrm{F}$ dan nilai satistik t. Dimana perhitungannya dapat dikatakan signifikan secara statistic apabila uji nilai statistiknya berada dalam daerah kritis (daerah dimana Ho ditolak). Sedangkan sebaliknya disebut tidak signifikan apabila uji nilai statistiknya berada dalam daerah dimana Ho diterima.

\section{Uji T}

Uji hipotesis $\mathrm{T}$ untuk mengetahui pengaruh variabel $\mathrm{X}$ terhadap variabel Y secara parsial digunakan uji-T dengan level signifikan $\alpha=0,05$. Jika nilai signifikan $>5 \%$ maka hipotesis yang dinyatakan ada pengaruh antara etika profesi $\left(\mathrm{X}_{1}\right)$, Kecerdasan Intelektual $\left(\mathrm{X}_{2}\right)$ terhadap pengambilan keputusan auditor ( $\mathrm{Y}$ ) adalah ditolak sedangkan jika nilai signifikan $<5 \%$ maka hipotesa yang dinyatakan akan diterima. 


\section{Koefisien determinasi $\left(\mathbf{R}^{\mathbf{2}}\right)$}

Analisa korelasi atau asosiasi merupakan satu dipembahasan tentang derajat keeratan hubungan antar variabel yang dinyatakan dengan koefisien korelasi. Hubungan antara variable bebas (X) dan variabel (Y) dapat bersifat:

1) Positif, artinya jika variabel $X$ naik, maka variabel $Y$ naik.

2) Negatif, artinya jika variabel $X$ turun, maka variabel $Y$ turun.

\section{Definisi Operasional Variabel}

\begin{tabular}{|c|c|c|c|c|}
\hline Variabel & Definisi Operasional & $\begin{array}{c}\text { Skala } \\
\text { Pengukuran }\end{array}$ & Rasio & Sumber \\
\hline $\begin{array}{l}\text { Struktur } \\
\text { Corporate } \\
\text { Governance } \\
\text { (X) }\end{array}$ & $\begin{array}{l}\text { Tata kelola perusahaan } \\
\text { yang menjelaskan } \\
\text { hubungan anatara } \\
\text { berbagai partisipan } \\
\text { dalam perusahaan yang } \\
\text { menentukan arah dan } \\
\text { kinerja perusahaan. } \\
\text { Pengertian corporate } \\
\text { governance secara } \\
\text { umum adalah sistem, } \\
\text { proses, dan seperangkat } \\
\text { peraturan yang } \\
\text { mengatur hubungan } \\
\text { antara berbagai pihak } \\
\text { yang berkepentingan } \\
\text { terutama dalam arti } \\
\text { sempit, hubungan } \\
\text { antara pemegang } \\
\text { saham, dewan } \\
\text { komsaris, dan dewan } \\
\text { dureksi demi } \\
\text { tercapainya tujuan } \\
\text { organisasi. }\end{array}$ & $\begin{array}{l}\text { Total Aset } \\
\text { Bulanan dan } \\
\text { Lap. Laba } \\
\text { Rugi CV. } \\
\text { Otopro } \\
\text { Mobilindo } \\
\text { Periode } \\
\text { Tahun } 2015 \text { - } \\
2017\end{array}$ & $\begin{array}{l}\text { Profitabilitas } \\
\qquad R O A \\
=\frac{L B}{T A} \times 100 \%\end{array}$ & [8] \\
\hline $\begin{array}{l}\text { Kondisi } \\
\text { Financial } \\
\text { Distress } \\
\text { (Y) }\end{array}$ & $\begin{array}{l}\text { Kesulitan keuangan } \\
\text { atau financial distress } \\
\text { merupakan keadaan } \\
\text { yang dimulai saat } \\
\text { perusahaan tidak dapat } \\
\text { memenuhi kewajiban } \\
\text { atau terindikasi tidak } \\
\text { dapat memenuhi } \\
\text { kewajibannya. } \\
\text { Financial distress } \\
\text { didefinisikan sebagai } \\
\text { tahap penurunan }\end{array}$ & $\begin{array}{l}\text { Laba Bersih } \\
\text { dan Beban } \\
\text { Bunga CV. } \\
\text { Otopro } \\
\text { Mobilindo } \\
\text { Periode } \\
\text { Tahun } 2015 \text { - } \\
2017\end{array}$ & $\begin{array}{c}\text { EBIT } \\
T I E R=\frac{E}{B B}\end{array}$ & [9] \\
\hline
\end{tabular}




\begin{tabular}{|l|l|l|l|}
\hline & kondisi keuangan yang & & \\
terjadi sebelum & & \\
terjadinya kebangkrutan & & \\
ataupun likuidasi. & & \\
Kondisi financial & & \\
distress tergambar dari & & \\
ketidakmampuan atau & & \\
tidak tersedianya dana & & \\
untuk membayar & & \\
kewajiban yang telah & & \\
jatuh tempo. Terdapat & & \\
perbedaan dalam & & \\
mengartikan kesulitan & & \\
keuangan pada & & \\
penelitian penelitian & & \\
terdahulu dan & & \\
perbedaan ini & & \\
tergantung pada cara & & \\
mengukurnya. & & \\
\hline
\end{tabular}

Penjelasan :

ROA = Return on Assets

LB $=$ Laba Bersih

TA $=$ Total Aset

TIER = Time Interest Earned Ratio

$\mathrm{E} \quad=\mathrm{EBIT}$

$\mathrm{BB}=$ Beban Bunga

\section{HASIL DAN PEMBAHASAN}

\section{Hasil Uji Normalitas}

One-Sample Kolmogorov-Smirnov Test

\begin{tabular}{|l|r|}
\hline & $\begin{array}{c}\text { Corporate } \\
\text { Governance }\end{array}$ \\
\hline Asymp. Sig. (2-tailed) & $.200^{\mathrm{c}, \mathrm{d}}$ \\
\hline
\end{tabular}

a. Test distribution is Normal.

Dari tabel 4.3 diatas menunjukkan bahwa terjadi normalitas pada Corporate governance terhadap kondisi financial distress karena nilai asymp sig 0,200 >0.05. Hal ini berarti bahwa uji asumsi klasik terpenuhi.

\section{Hasil Analisis Regresi Linear Sederhana}

\begin{tabular}{|l|l|}
\hline \multicolumn{1}{|c|}{ Variabel } & \multicolumn{1}{c|}{ Koefisien Regresi } \\
\hline Konstanta & 38449.183 \\
\hline Corporate Governance (X) & 0.067 \\
\hline
\end{tabular}


Berdasarkan tabel 4.4 maka ringkasan hasil pengujian dapat diformulasikan persamaan regresinya sebagai berikut:

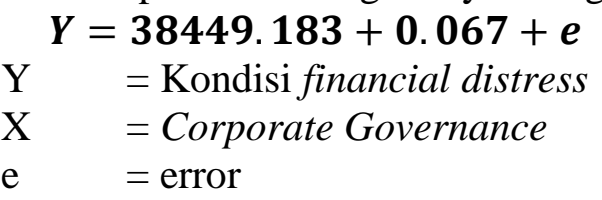

Dari persamaan tersebut dapat ditarik kesimpulan bahwa, konstanta menunjukkan tanpa variabel bebas corporate governance sebesar nilai konstanta yang dihasilkan yaitu 38449.183. Namun jika ada variabel corporate governance maka financial distress akan meningkat disebabkan variabel corporate governance memberikan pengaruh terhadap financial distress.

\section{Hasil Uji Autokorelasi}

\begin{tabular}{|l|lr|}
\hline Model & \multicolumn{2}{|c|}{ Durbin-Watson } \\
\hline 1 & \multicolumn{2}{|c|}{1.826} \\
\hline
\end{tabular}

Berdasarkan tabel 4.5 nilai Durbin-Watson yang digunakan untuk mengukur seberapa jauh atau seberapa besar hubungan antara variabel independen degan variabel dependen. Berdasarkan tabel diatas diperoleh nilai Durbin-Watson sebesar 1,826. Dilihat dari tabel DW didapat dari nilai DU yaitu 1,5245 dan nilai 4-DU adalah 2,4755 maka sesuai dengan rumus uji autokorelasi 1,5245 $<1,826<2,4755$. Dapat disimpulkan bahwa tidak terjadi masalah autokorelasi pada penelitian ini dan penelitian dapat dilanjutkan.

\section{Hasil Uji T}

\begin{tabular}{|l|c|c|}
\hline Model & T & Sig. \\
\hline (Constant) & 1.857 & .072 \\
CG & 1.491 & 0.145 \\
\hline
\end{tabular}

Berdasarkan table 4.6 menunjukkan hasil variable independen (Corporate Governance) berpengaruh negatif terhadap variabel dependen (Kondisi Financial Distress), karena nilai hasil uji T menunjukkan 0,145>0,05.

\section{Hasil Koefesien Determinasi}

Model Summary ${ }^{b}$

\begin{tabular}{|l|c|c|c|c|}
\hline & & $\mathrm{R}$ & $\begin{array}{c}\text { Adjusted } \\
\mathrm{R}\end{array}$ & $\begin{array}{c}\text { Std. Error of } \\
\text { the Estimate }\end{array}$ \\
\hline
\end{tabular}




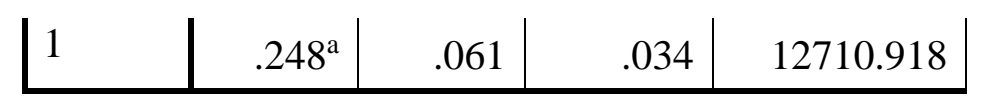

a. Predictors: (Constant), CG

b. Dependent Variable: KFD

Berdasarkan tabel 4.7 maka ringkasan hasil korelasi dan determinasi adalah sebagai berikut:

maka ringkasan hasil korelasi dan determinasi menunjukkan bahwa nilai koefisien Adjusted $R$ Square adalah sebesar 0,061, hal ini berarti $6,1 \%$ variabel kondisi financial distress dapat dijelaskan oleh variabel corporate governance. Sedangkan sisanya $(100 \%-6,1 \%=93,9 \%)$, dipengaruhi oleh

\section{Hasil Uji Hipotesis} variabel-variabel lain yang tidak dijelaskan dalam penelitian ini.

Dapat diketahui nilai hitung untuk variabel corporate governance 1,491 dengan signifikansi 0,145. Nilai Sig. variabel corporate governance (X) sebesar $0,145>0,05=0$ maka Ha ditolak, berarti terdapat pengaruh negatif antara variabel corporate governance $(\mathrm{X})$ terhadap kondisi financial distress.

\section{SIMPULAN}

Berdasarkan analisa data, interpretasi hasil penelitian, dan pembahasan yang telah disampaikan sebelumnya, maka dapat dikemukakan beberapa kesimpulan dari hasil penelitian ini sebagai berikut:

1. Seluruh variabel dalam penelitian ini berdistribusi normal dibuktikan dengan nilai asymp.sig (2 tailed) besar dari 0.05 yaitu sebesar 0,200.

2. Persamaan regresi linear sederhana dalam penelitian ini yaitu $\mathrm{y}=$ $38449.183+0,067 \mathrm{x}+e$

3. Variabel corporate governance berpengaruhi negatif terhadap kondisi financial distress yang dibuktikan dengan nilai signifikansi $>0,05$ yaitu sebesar 0,145 .

4. Dengan nilai signifikansi ,0145>0,05 = o , maka Ha ditolak, berarti terdapat pengaruh negatif antara variable struktur corporate governance (X) terhadap kondisi financial distress $(\mathrm{Y})$.

\section{UCAPAN TERIMA KASIH}

Syukur Alhamdulillah penulis ucapkan kepada Allah SWT, yang telah memberikan rahmat dan hidayah-Nya, sehingga akhirnya penulis dapat menyelesaikan Penelitian ini dengan judul "Pengaruh Corporate Governance Terhadap Kondisi Financial Distress Pada Perusahaan CV. Otopro Mobilindo“.

Dalam menyusun skripsi ini banyak sekali pihak - pihak yang memberikan bantuan dan dukungan kepada penulis baik secara akademik maupun non akademik. Pada kesempatan ini panulis ingin menyampaikan ucapan terima kasih yang tulus kepada semua pihak yang telah memberikan dukungan, bimbingan, semangat, motivasi, dan doa.

Oleh karna itu dalam kesempatan ini penulis ingin mengucapkan terima kasih yang sebesar - besarnya kepada : 
1. Bapak Febryandhie Ananda, SE, M.Si, selaku Ketua STIE KBP, dosen pembimbing akademik sekaligus dosen pembimbing dalam pembuatan skripsi ini yang telah memberikan pengarahan dan saran serta dorongan yang sangat berarti bagi penulis dalam penyelesaian skripsi ini.

2. Ibuk Lidya Marta, SE, MM, selaku wakil Ketua STIE KBP.

3. Ibuk Dewi Zulvia, SE, MM. selaku Ketua Prodi Akuntansi yang juga memberikan pengarahan dan saran bagi penulis.

4. Bapak Wahyu Amran dan Andrew Aditya selaku Pimpinan CV. Otopro Mobilindo yang telah memberikan izin tempat bagi penulis untuk melakukan penelitian.

\section{DAFTAR PUSTAKA}

[1] H. Indra, "Analisis Pengaruh Struktur Kepemilikan dan Karakteristik Perusahaan Terhadap Kemungkinan Kesulitan Keuangan," Univ.

Muhammadiyah Surakarta, 2014.

[2] I. G. A. A. P. Cinantya and N. K. L. A. Merkusiwati, "Pengaruh Corporate Governance, Financial Indicators dan Ukuran Perusahaan pada Financial Distress," Fak. Ekon. dan Bisnis Univ. Udayana, vol. 10, no. 3, pp. 897 915, 2015.

[3] F. Ananda, R. D. Putra, and V. S. Hendrastyo, "Kesuksesan Implementasi System Application Product (SAP) studi kasus di PT. Semen Padang," J. Pundi, vol. 1, no. 1, pp. 1-10, 2017.

[4] F. Ananda and D. Zulvia, "Indikasi machiavellianism dalam pembuatan keputusan etis auditor pemula," Benefita, vol. 3, no. September, pp. 357369, 2018.

[5] O. E. Hanifah, "Pengaruh Struktur Corporate Governance Dan Financial Indicators Terhadap Kondisi Financial Distress," Univ. Diponegoro, vol. 2, no. ISSN (Online): 2337-3806, pp. 1-80, 2013.

[6] T. R. I. Bodroastuti, "Pengaruh Struktur Corporate Governance terhadap Financial Distress The Influence of Corporate Governance Structure to Financial Distress," STIE Widya Manggala Semarang, no. 2000, pp. 1-15, 2009.

[7] Sugiyono, Metode Penelitian Kuantitatif, Kualitatif dan R\&D. Bandung: Alfabeta, 2016.

[8] L. P. Mayangsari and Andayani, "Pengaruh Good Corporate Governance Dan Kinerja Keuangan Terhadap Financial Distress," STIESIA Surabaya, vol. 4, no. 4, pp. 1-18, 2015.

[9] I. Rahayu, "Pengaruh Struktur Corporate Governance Terhadap Kesulitan Keuangan," Univ. Lampung, 2017. 